Jurnal Media Pertanian Vol. 2 No. 2 Tahun 2017 Hal. 73 - 84

Media Komunikasi Hasil Penelitian dan Review Literatur Bidang Ilmu Agronomi ISSN print $2503-1279$

ISSN online $2581-1606$

\title{
MODEL DISTRIBUSI BENIH KEDELAI LABEL BIRU DENGAN SISTEM JABALSIM DAN JABALSIM TERKENDALI DI KABUPATEN TANJUNG JABUNG TIMUR
}

\author{
Rudi Hartawan $^{1 *}$ dan Edy Marwan ${ }^{2}$ \\ ${ }^{1}$ Program Studi Agroteknologi, Fakultas Pertanian Universitas Batanghari \\ J1. Slamet Riyadi, Broni Jambi. 36122. Telp. +62074160103 \\ ${ }^{2}$ Program Studi Agribisnis, Fakultas Pertanian Universitas Muhammadiyah Bengkulu \\ Jl. Bali Po. Box. 118 Bengkulu, 38119 Telp. +6207322765 \\ *email korespondensi: rudi2810@ yahoo.com
}

\begin{abstract}
Abtract
In line with the national program to improve soybean production, Tanjung Jabung Timur (Tanjabtim) assessed as having the potential of natural resources for development of soybean. Generally soybean seed supply in Tanjabtim done in nonformal through the network system (Jabalsim). The study aimed to determine the soybean seed supply system that runs all along, inventory weaknesses and strengths in the provision of seeds and strategize so Jabalsim Controlled models more commonly used by farmers. The research has been carried out in January-May 2015. The primary data obtained from interviews with 20 groups of growers and users. Hiking circulation of seeds is observed in the Simpang and Margo Mulyo village in District of Rantau Rasau. Both villages are located in Tanjabtim. The location is outside Tanjabtim is the city of Jambi, Muaro Jambi Regency, Bungo Regency and Tebo Regency. Interview data were tabulated and made Jabalsim system model and Controlled Jabalsim. Data from interviews were also used as a way to make a SWOT analysis to encourage the migration of Jabalsim to Controlled Jabalsim. Strategies that can be used to enable the migration of Jabalsim to Controlled Jabalsim is to involve BPSB start of the process permit application until the issuance of seeds certificates.
\end{abstract}

Keywords: Seeds production, soybeans, and tidal swamp

\begin{abstract}
Abstrak
Sejalan dengan program peningkatan produksi kedelai nasional, Kabupaten Tanjung Jabung Timur dinilai mempunyai potensi sumberdaya alam untuk pengembangan kedelai. Umumnya penyediaan benih kedelai di Kabupaten Tanjung Jabung Timur dilakukan secara non-formal melalui sistem jaringan benih antar lapang antar musim (Jabalsim). Penelitian yang bertujuan untuk mengetahui sistem penyediaan benih kedelai yang berjalan selama ini, menginventarisasi kelemahan dan kekuatan dalam penyediaan benih dan menyusun strategi agar model Jabalsim Terkendali lebih umum digunakan petani dalam penyediaan benih bermutu telah dilaksanakan pada bulan Januari-Mei 2015. Data primer didapat dari wawancara dengan 20 kelompok penangkar dan pengguna. Jalur peredaran benih yang diamati adalah Desa Simpang di Kecamatan Berbak, Desa Margo Mulyo di Kecamatan Rantau Rasau. Kedua desa tersebut berada di Kabupaten Tanjung Jabung Timur. Lokasi yang berada di luar Kabupaten Tanjung Jabung Timur adalah Kota Jambi, Kabupaten Muaro Jambi, Kabupaten Bungo dan Kabupaten Tebo. Data hasil wawancara ditabulasi dan dibuatkan model sistem Jabalsim dan Jabalsim Terkendali. Data hasil wawancara juga digunakan sebagai jalan untuk membuat analisis SWOT untuk mendorong migrasi dari sistem Jabalsim ke Jabalsim
\end{abstract}


Jurnal Media Pertanian Vol. 2 No. 2 Tahun 2017 Hal. 73 - 84

Media Komunikasi Hasil Penelitian dan Review Literatur Bidang Ilmu Agronomi ISSN print $2503-1279$

ISSN online $2581-1606$

Terkendali. Strategi yang dapat digunakan agar terjadi migrasi dari sistem Jabalsim ke Jabalsim Terkendali adalah dengan melibatkan BPSB mulai dari proses pengajuan izin pertanaman sampai pengeluaran sertifikat benih.

Kata kunci: Produksi benih, kedelai, rawa gambut dan pasang surut

\section{PENDAHULUAN}

Kabupaten Tanjung Jabung Timur merupakan sentra kedelai di Provinsi Jambi. Tahun 2015 luas tanam mencapai 628 ha dengan total produksi 1.028 ton (Tanjung Jabung Timur dalam Angka, 2016). Kegairahan petani menanam komoditas ini masih terjaga walaupun kendala alam sering mengganggu aktivitas budidaya. Sejalan dengan program peningkatan produksi kedelai nasional dalam rangka mencapai swasembada pada tahun 2018 ini, Propinsi Jambi khususnya Kabupaten Tanjung Jabung Timur dinilai mempunyai potensi sumberdaya alam (khususnya lahan pasang surut dan mineral) yang cocok untuk pengembangan kedelai melalui ekstensifikasi.

Kendala utama yang ditemui dalam rangka pengembangan komoditas ini di Tanjung Jabung Timur adalah: (a) kurangnya dukungan permodalan bagi petani untuk penerapan teknologi produksi, (b) rendahnya gairah petani untuk memproduksi kedelai karena harga kedelai yang kurang menarik disebabkan kedelai impor tersedia melimpah, dan (c) dukungan subsistem penyediaan/ pengadaan benih kedelai varietas unggul bermutu tinggi belum optimal.

Penyediaan benih varietas unggul baru bermutu tinggi bagi petani dalam rangka peningkatan produksi kedelai, baik secara intensifikasi maupun ekstensifikasi, merupakan hal yang sangat penting. Hal itu disebabkan, melalui benih varietas unggul baru itulah teknologi budidaya akan ditanggapi dan ditransformasi sedemikian rupa sehingga potensi genetik varietas akan terekspresikan. Umumnya penyediaan benih kedelai bagi petani di Indonesia dan khususnya di Kabupaten Tanjung Jabung Timur selama ini sebagian besar dilakukan secara non-formal melalui system Jabalsim (Jalinan Arus Benih Antar Lapang dan Musim), karena pengadaan penih kedelai bersertifikat hingga kini belum dapat terlaksana secara optimal (Harnowo 2005; Nugroho dan Subandi, 2002). Revitalisasi Jabalsim tanpa sertifikat menjadi besertifikat dicanangkan tahun 2008 dengan istilah Jabalsim Terkendali (Nurasa, 2007). Suryana (2009) dan Adie et al. (2013) menyatakan bahwa Jabalsim Terkendali merupakan upaya penyebaran benih kedelai bersertifikat dengan kualitas yang terjamin, dilaksanakan dalam satu tahun. Benih kedelai tidak mengalami proses penyimpanan karena segera didistribusikan setelah dipanen. Pemahaman pola distribusi benih kedelai sistem Jabalsim dan Jabalsim Terkendali diperlukan untuk mengetahui model penyebarannya dari produsen (penangkar) sampai ke konsumennya yaitu petani kedelai konsumsi.

Benih merupakan komponen utama dalam budidaya tanaman termasuk kedelai. Penggunaan benih bermutu (bersertifikat) masih rendah karena berbagai alasan; mulai dari harga sampai kesulitan petani terhadap akses benih bermutu itu sendiri. Dampak dari akses yang rendah terhadap benih bermutu, maka petani produsen kedelai konsumsi berupaya mendapatkan benih kedelai (tanpa sertifikat atau dengan setifikat). Peredaran benih kedelai tanpa sertifikat antar petani dikenal dengan Jabalsim, sedangkan peredaran benih kedelai dengan sertifikat dikenal dengan istilah Jabalsim Terkendali. Perlu diketahui model dan pola penyebaran kedua sistem ini dengan harapan model Jabalsim dapat dikurangi dan Jabalsim Terkendali dapat ditingkatkan. Sistem Jabalsim Terkendali akan meningkatkan peluang petani mendapatkan benih kedelai bersertifikat, 
Jurnal Media Pertanian Vol. 2 No. 2 Tahun 2017 Hal. 73 - 84

Media Komunikasi Hasil Penelitian dan Review Literatur Bidang Ilmu Agronomi ISSN print $2503-1279$

ISSN online $2581-1606$

tepat waktu dengan harga terjangkau. Informasi mengenai Jabalsim dan upaya migrasi ke Jabalsim Terkendali telah didapat melalui penelitian dengan tujuan (a) mengetahui sistem penyediaan benih kedelai yang berjalan selama ini, (b) menginventarisasi kelemahan dan kekuatan dalam penyediaan benih kedelai di Kabupaten Tanjung Jabung Timur, dan (c) menyusun strategi agar model Jabalsim Terkendali lebih umum digunakan petani dalam penyediaan benih kedelai bermutu.

\section{METODE PENELITIAN}

Lokasi penelitian adalah tempat dimana benih kedelai dihasilkan (di luar Kabupaten Tanjung Jabung Timur) dan digunakan di Tanjung Jabung Timur serta desadesa yang memproduksi benih kedelai yang disebarkan ke lokasi-lokasi tanam di dalam Kabupaten Tanjung Jabung Timur itu sendiri. Lokasi yang telah teridentifikasi adalah Desa Simpang di Kecamatan Berbak, Desa Margo Mulyo di Kecamatan Rantau Rasau. Kedua desa tersebut berada di Kabupaten Tanjung Jabung Timur. Lokasi yang berada di luar Kabupaten Tanjung Jabung Timur adalah Balai Benih Induk Sebapo di Kecamatan Sebapo Kabupaten Muaro Jambi, Kelompok Tani penangkar benih kedelai di Desa Teluk Rendah Kecamatn Tebo Ulu, Kabupaten Tebo dan BBI Margoyoso di Kabupaten Bungo.

Kegiatan ini dilaksanakan dengan survei lapangan pada bulan Januari-Mei 2015. Menurut Singarimbun dan Efendi (2008) bahwa survey atau self-administered survey adalah metode pengumpulan data primer dengan memberikan pertanyaan-pertanyaan kepada responden individu. Data primer diambil dari wawancara dengan 10 petani pada masing-masing dari 20 kelompok penangkar dan pengguna. Sepuluh orang petani yang dijadikan sampel dipilih dengan sistem simple random sampling dengan metode seperi yang dijelaskan oleh Sugiono (2009).

Aspek-aspek yang digali meliputi: tanggap petani terhadap upaya peningkatan produksi kedelai di wilayah ini, kendala-kendala yang dihadapi, teknologi produksi yang diterapkan, tingkat produktivitas kedelai yang dicapai selama ini dan sistem penyediaan benih. Data sekunder (yang berkaitan dengan luas area, produksi dan produktivitas kedelai) diperoleh dari berbagai instansi terkait, yaitu Dinas Tanaman Pangan dan Hortikultura Kabupaten Tanjung Jabung Timur dan Dinas Tanaman Pangan, Hortikultura dan Peternakan Provinsi Jambi, Balai Pengawasan dan Sertifikasi Benih Tanaman Pangan dan Hortikultura Provinsi Jambi, Balai Benih Induk Palawija di Sebapo dan Balai Benih Induk Margoyoso di Muaro Bungo.

Data hasil wawancara dengan petani produsen kedelai konsumsi dan produsen benih kedelai ditabulasi dan dibuatkan model sistem Jabalsim dan Jabalsim Terkendali. Data hasil wawancara juga digunakan sebagai jalan untuk membuat analisis SWOT untuk mendorong migrasi dari sistem Jabalsim ke Jabalsim Terkendali.

\section{HASIL DAN PEMBAHASAN}

\section{Sistem Penyediaan Benih Kedelai yang Berjalan Selama Ini}

Dukungan terhadap penggunaan benih unggul bersertifikat memerlukan sistem pengelolaan produksi dan distribusi benih yang baik sehingga mampu menyediakan benih yang sesuai dengan kebutuhan petani, yaitu benih dengan varietas, mutu, jumlah, waktu, lokasi dan harga yang tepat. Menurut Supadi (2008), petani dan penangkar/kelompok penangkar benih harus disertakan dalam penyediaan benih unggul bersertifikat. Kegiatan ini sangat penting, walaupun disisi lain masih memiliki 
Jurnal Media Pertanian Vol. 2 No. 2 Tahun 2017 Hal. 73 - 84

Media Komunikasi Hasil Penelitian dan Review Literatur Bidang Ilmu Agronomi ISSN print $2503-1279$

ISSN online $2581-1606$

keterbatasan seperti luas areal produksi dan sumber daya manusia, prasarana dan sarana, serta modal. Jadual produksi benih kedelai di Tanjung Jabung Timur disajikan pada Gambar 1.

\begin{tabular}{|c|c|c|c|c|c|c|c|c|c|c|c|}
\hline \multicolumn{1}{|c|}{ Bulan } \\
\hline 4 & 5 & 6 & 7 & 8 & 9 & 10 & 11 & 12 & 1 & 2 & 3 \\
\hline \multicolumn{3}{|c|}{ MK } & & & & & & & & \\
\hline \multicolumn{3}{|c|}{ Produksi benih kedelai } & \multicolumn{3}{c|}{ MK-MH } & & & & MH \\
\hline \multicolumn{2}{|c|}{} & & & \multicolumn{3}{c|}{ Produksi benih kedelai } & \multicolumn{5}{c|}{ Komoditas lainnya } \\
\hline
\end{tabular}

Gambar 1. Jadual produksi benih di Kabupaten Tanjung Jabung Timur

Pada musim kemarau atau musim tanam pertama untuk daerah pasang surut pada bulan April sampai Juli produksi benih kedelai berjalan dengan baik. Pada bulanbulan tersebut kondisi limpasan banjir sudah turun dan produksi benih dapat dilakukan. Kegiatan tanam musim kemarau sampai musim hujan pada bulan Agustus sampai November, dilakukan pada daerah yang agak tinggi atau kondisi limpasan banjir tidak terlalu parah sehingga tinggi genangan pada musim hujan Oktober dan November tidak sampai menggenang areal pertanaman. Pada bulan Desember samai Maret, produksi benih tidak dapat dilakukan karena kondisi limpasan banjir masih tinggi sehingga kegiatan pertanaman tidak dapat dilakukan.

Sumber benih yang digunakan penangkar dalam produksi benih kedelai sangat beragam. Berdasarkan hasil pengamatan ada lima cara yang dilakukan penangkar untuk mendapatkan benih. Data disajikan pada Tabel 1 berikut.

Tabel 1. Cara memperoleh benih yang digunakan untuk produksi benih kedelai

\begin{tabular}{llc}
\hline No. & \multicolumn{1}{c}{ Asal Benih } & Petani Pengguna (\%) \\
\hline 1. & Instansi pemerintah (BBI Sebapo, BPTP Jambi dan & 40 \\
& Dinas Pertanian dan Tanaman Pangan Kab. & \\
& Tanjabtim) & 10 \\
2. & Petugas PPL & 15 \\
3. & Benih Sendiri & 5 \\
4. & Beli di Toko Pertanian & 30 \\
5. & Beli dengan Penangkar lain/Sesama petani & 100 \\
\hline
\end{tabular}

Tabel 2 menggambarkan penangkar benih memperoleh bahan tanam dari berbagai macam. Diyakini bahwa jika yang memberikan bahan tanam (benih) berasal dari instansi pemerintah, maka sumber benih tersebut dari kelas benih pokok.Turunan pertama benih pokok ini dikenal sebagai benih sebar. Benih sebar inilah yang digunakan oleh petani yang akan menghasilkan kedelai konsumsi.

Benih yang berasal dari penyuluh pertanian lapangan (PPL) yang jumlahnya mencapai $10 \%$ juga diyakini dari kelas benih pokok. Bisa jadi benih tersebut dari instansi pemerintah yang disalurkan melalui PPL. Sebanyk 50\% sumber benih berasal dari benih sendiri $(15 \%)$, beli di toko pertanian $(5 \%)$ dan beli dari penangkar atau sesame petani sebesar $30 \%$.

Sebanyak 50\% sumber benih yang berasal dari instansi pemerintah dan PPL diyakini sebagai benih yang berkualitas (tersertifikat). Sebanyak 50\% lainnya dipenuhi 
Jurnal Media Pertanian Vol. 2 No. 2 Tahun 2017 Hal. 73 - 84

Media Komunikasi Hasil Penelitian dan Review Literatur Bidang Ilmu Agronomi ISSN print $2503-1279$

ISSN online $2581-1606$

dari sistem Jabalsim non formal dan diduga tidak bersertifikat sehingga diragukan berasal dari kelas benih pokok. Benih yang diproduksi oleh petani penangkar tersebut tidak dapat disertifikasi karena ketidakjelasan sumber benih yang digunakan.

Permasalahan lain yang berhasil diamati dari produksi benih kedelai yang sumber benihnya berasal dari pemerintah umumnya berupa proyek perluasan areal tanam karena adanya pesanan benih dari wilayah lainnya. Benih yang dihasilkan dari penangkar tersebut dibeli oleh pemerintah untuk digunakan di daerah lain atau dijadikan stok untuk kebutuhan tanam mendadak. Cara ini dilakukan karena kebanyakan Balai Benih Umum (BBU) yang berada di kabupaten tidak lagi melaksanakan produksi benih kedelai, kalaupun ada sangat terbatas. Berikut disajikan model distribusi benih sistem Jabalsim di Kabupaten Tanjung Jabung Timur.

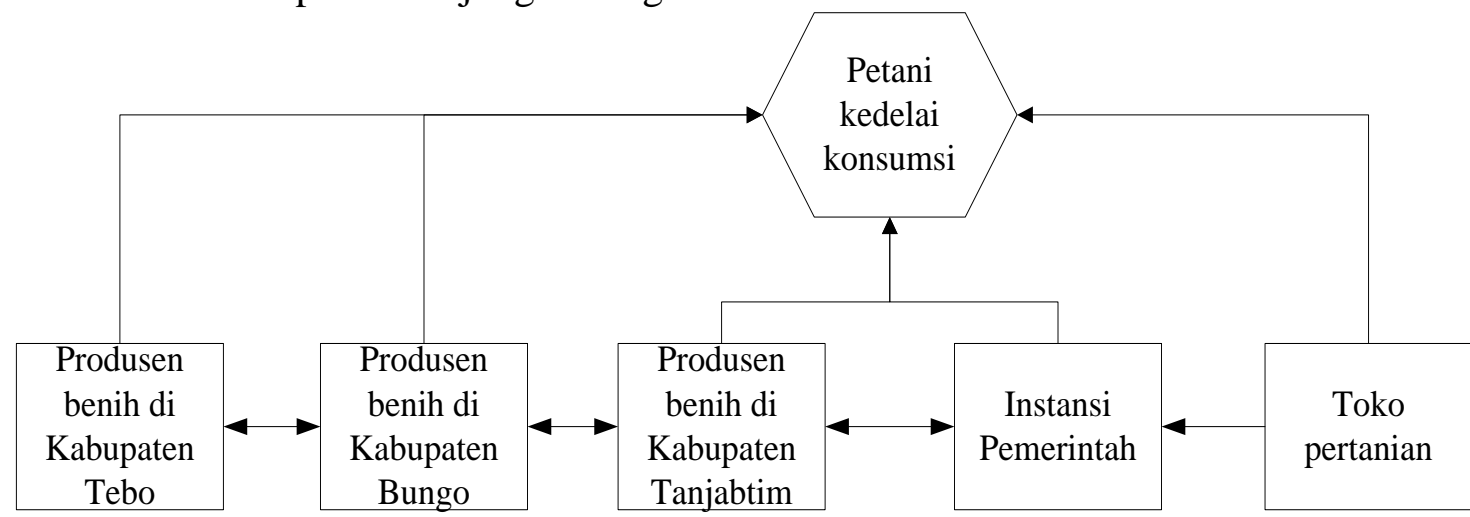

Gambar 2. Model distribusi benih kedelai sistem Jabalsim di Kabupaten Tanjung Jabung Timur

Gambar 2 menjelaskan model distribusi benih satu arah dan dua arah. Gerakan satu arah hanya terjadi bila petani kedelai konsumsi membutuhkan benih untuk aktivitas pertanaman dan Instansi pemerintah membeli benih dari toko pertanian. Gerakan dua arah terjadi saat benih beredar antar kabupaten dan instansi pemerintah. Gambar 2 juga mengindikasikan pergerakan benih sistem Jabalsim. Jabalsim ini dapat terjadi di dalam Kabupaten Tanjung Jabung Timur (penangkar benih di Kecamatan Berbak, penangkar benih di Kecamatan Rantau Rasau dan Toko Pertanian). Jabalsim juga terjadi antara penangkar di Kabupaten Tanjung Jabung Timur dengan penangkar di luar kabupaten tersebut.

Umumnya benih dengan sistem Jabalsim tidak jelas asal usulnya dan kualitasnya beragam (kecuali dari instansi pemerintah). Menurut Heriyanto (2012) bahwa benih sistem Jabalsim dikuasai oleh pedagang sehingga mengabaikan teknik budidaya, pasca panen dan penyimpanan. Dampaknya adalah daya tumbuh benih cepat sekali mengalami penurunan (daya tumbuh kurang dari $80 \%$ dalam waktu 3 bulan). Kualitas ini tidak lagi sesuai dengan standar mutu benih (Badan Standardisasi Nasional, 2003).

\section{Inventarisasi Kekuatan dan Kelemahan dalam Penyediaan Benih Kedelai}

Inventarisasi kekuatan, kelemahan, peluang dan ancaman dalam kegiatan penyediaan benih kedelai perlu dilakukan agar benih kedelai yang beredar dengan sistem Jabalsim dapat dikendalikan. Pengendalian sistem dikenal dengan Jabalsim Terkendali. Berikut disajikan inventarisasi kekuatan, kelemahan, peluang dan ancaman dalam penyediaan benih kedelai di Kabupaten Tanjung Jabung Timur. 
Jurnal Media Pertanian Vol. 2 No. 2 Tahun 2017 Hal. 73 - 84

Media Komunikasi Hasil Penelitian dan Review Literatur Bidang Ilmu Agronomi ISSN print $2503-1279$

ISSN online $2581-1606$

Tabel 2. Kekuatan, kelemahan, peluang dan ancaman dalam penyediaan benih kedelai di Kabupaten Tanjung Jabung Timur

\begin{tabular}{|c|c|}
\hline Kekuatan & Kelemahan \\
\hline $\begin{array}{l}\text { 1. Kampanye yang masif dari PPL } \\
\text { tentang pentingnya penggunaan benih } \\
\text { bermutu } \\
\text { 2. Benih bermutu terbukti memberikan } \\
\text { hasil benih yang tinggi } \\
\text { 3. Benih bermutu berpeluang untuk } \\
\text { mendapat sertifikat dari BPSB }\end{array}$ & $\begin{array}{l}\text { 1. Prinsip enam tepat belum berjalan } \\
\text { dengan baik } \\
\text { 2. Harga benih masih dianggap tinggi } \\
\text { oleh petani kedelai konsumsi } \\
\text { 3. Penanganan pasca panen dengan } \\
\text { peralatan yang sederhana }\end{array}$ \\
\hline Peluang & Ancaman \\
\hline $\begin{array}{l}\text { 1. Areal pertanaman yang luas } \\
\text { membutuhkan benih bermutu yang } \\
\text { banyak } \\
\text { 2. Bantuan benih pokok dari pemerintah } \\
\text { untuk produksi benih sebar }\end{array}$ & $\begin{array}{l}\text { 1. Benih kedelai dengan sertifikat palsu } \\
\text { beredar di pasaran } \\
\text { 2. Gagal sertifikasi karena proses } \\
\text { budidaya dan pasca panen yang tidak } \\
\text { tepat }\end{array}$ \\
\hline $\begin{array}{l}\text { 3. Benih bersertifikat dapat dijual lintas } \\
\text { daerah }\end{array}$ & 3. Benih tanpa sertifikat berharga rendah \\
\hline
\end{tabular}

Pemerintah terus berupaya meningkatkan penggunaan benih bermutu dikalangan petani dan petani penangkar. Cara yang dilakukan adalah mengadakan temu lapang antara petani dengan PPL dan PPL membuatkan demplot yang bekerjasama dengan petani untuk menunjukkan secara langsung manfaat dari penggunaan benih bermutu. Kegiatan demplot dan temu lapang ini juga dapat dilakukan oleh pihak perguruan tinggi. Salah satu kegiatan yang dilaksanakan oleh Nengsih dan Hartawan (2016) dengan menggunakan skim pengabdian kepada masyarakat yaitu ipteks bagi masyarakat, melaksanakan demplot produksi benih kedelai label biru di Desa Margo Mulyo Kecamatan Rantau Rasau dan Desa Simpang di Kecamatan Berbak. Hasil yang didapat dari kegiatan ini sangat memuaskan dan mendapat respon yang tinggi. Pada awalnya kegagalan sertifikasi mencapai $45 \%$, maka dengan pelaksanaan demplot maka kegagalan sertifikasi menjadi 0\%. Cara-cara seperti ini akan meningkatkan kepercayaan petani terhadap benih bermutu.

Menurut Razi (2008) beberapa aspek yang masih perlu dibenahi dalam penyediaan benih kedelai bermutu untuk mendukung proses Jabalsim terkendali adalah prinsip enam tepat yang belum berjalan dengan baik, harga benih bermutu yang masih terasa tinggi dan peralatan pasca panen yang masih sederhana. Prinsip enam tepat dalam produksi benih adalah tepat jumlah, tepat varitas, tepat mutu, tepat waktu, tepat lokasi, dan tepat harga. Kegagalan salah satu dari enam prinsip ini dapat mengakibatkan turunnya penggunaan benih bermutu.

Areal potensial untuk pertanaman kedelai di Kabupaten Tanjung Jabung Timur mencapai 5.000 an hektar. Luasan tanam aktual tahun 2014-2015 baru mencapai 682 hektar. Satu hektar pertanaman kedelai membutuhkan benih bermutu sebanyak $50 \mathrm{~kg}$, maka dalam satu musim tanam membutuhkan benih sebanyak 165 ton. Jika nilai $1 \mathrm{~kg}$ mencapai 7.500 maka nilai benih itu mencapai Rp. 255.750.000,00.

Pemerintah juga membantu meningkatkan penggunaan benih bermutu dengan memberikan bantuan benih kepada para petani penangkar. Biasanya pemerintah juga langsung membeli benih tersebut yang nantinya akan disebarkan pada daerah lain yang 
Jurnal Media Pertanian Vol. 2 No. 2 Tahun 2017 Hal. 73 - 84

Media Komunikasi Hasil Penelitian dan Review Literatur Bidang Ilmu Agronomi ISSN print $2503-1279$

ISSN online $2581-1606$

membutuhkan. Cara seperti ini biasa dilakukan oleh Balai Benih Induk Sebapo, Muaro Jambi dan BPTP Jambi (Triyanto, 2015², Komunikasi Pribadi). Penggunaan benih unggul sebagi sumber benih akan meningkatkan peluang keberhasilan sertifikasi seperti yang telah disebutkan sebelumnya. Nilai benih yang bersertifikat akan tinggi dan dapat diperjual belikan ke daerah lain.

Upaya mewujudkan Jabalsim Terkendali memiliki banyak ancaman. Beberapa ancaman yang terdata adalah benih bersertifikat palsu, proses produksi benih yang tidak tepat dan harga benih akan jatuh karena ketiadaan sertifikat. Benih bersertifkat palsu dapat saja terjadi dalam proses Jabalsim. Proses ini tidak dikendalikan sehingga ada beberapa oknum yang mengambila peluang dengan membuat sertifikat palsu guna meningkatkan harga jual. Kekecewaan petani sering terjadi yang berdampak terhadap rendahnya kepercayaan dalam penggunaan benih bermutu. Kejadian semacam ini perlu ditindaklanjuti dengan cara pengamatan langsung ke lapangan dan menindaklanjuti laporan para pengguna benih bermutu. Instansi yang diharapkan melaksanakan kegiatan ini adalah BPSB Provinsi Jambi dengan menggunakan pegawainya yang disebarkan ke daerah-daerah.

Kejadian gagal sertifikasi sangat mengganggu pengambalian modal produksi yang telah dikeluarkan oleh para petani. Menurut Nengsih dan Hartawan (2016), umumnya kadar air dan campuran varietas lain menempati urutan pertama dan kedua yang menyebabkan benih tersebut gagal dalam proses sertifikasi. Para petani penangkar perlu dilatih tentang tata cara pengeringan benih yang tepat karena pengeringan kedelai untuk benih sangat berbeda dengan pengeringan kedelai untuk konsumsi. Bantuan peralatan untuk pengujian kadar air di lapangan sangat penting agar ketepatan kadar air dalam proses penjemuran dapat terjadi.

\section{Strategi Agar Model Jabalsim Terkendali Lebih Umum Digunakan Petani dalam Penyediaan Benih Kedelai Bermutu}

Jabalsim Terkendali adalah pengembangan dari Jabalsim. Penambahan dari Jabalsim adalah adanya kendali mutu dalam bentuk sertifikasi sehingga benih yang dijual memeliki keterangan setifikat yang dikeluarkan oleh pihak yang berwenang, dalam hal ini adalah BPSB Provinsi Jambi. Konsep Jabalsim Terkendali sangat potensial mengingat lahan pertanian yang luas dan kebutuhan benih yang tinggi akan sangat terhambat bila sistem enam tepat tidak berjalan dengan baik. Sistem Jabalsim Terkendali akan mendekatkan jarak petani dengan sumber benih sehingga dapat mereduksi waktu dan memperpendek rantai suplai benih dari produsen ke konsumen.

Sistem penyediaan dan distribusi benih secara Jabalsim Terkendali akan memberi keuntungan antara lain; 1) menghindari periode penyimpanan yang terlalu lama, 2) selalu terpenuhinya kebutuhan benih yang baru dengan mutu yang tinggi, dan 3) harga benih dapat relatif lebih murah karena tidak dibebani biaya penyimpanan. Model yang diusulkan dalam penyediaan benih kedelai bermutu di Kabupaten Tanjung Jabung Timur disajikan pada Gambar 3.

\footnotetext{
${ }^{1}$ Ketua Kelompok Tani, Penangkar Benih Kedelai, Desa Simpang, Kecamatan Berbak, Tanjung Jabung Timur 


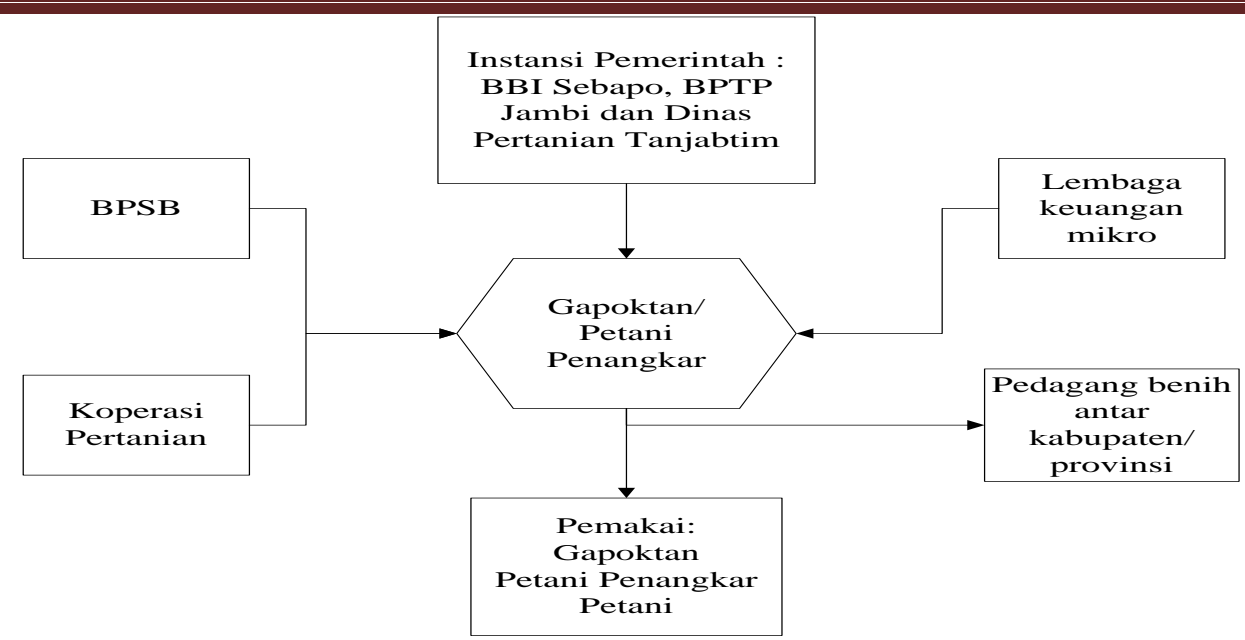

Gambar 3. Model ideal yang diusulkan untuk penyediaan benih kedelai bermutu di Kabupaten Tanjung Jabung Timur

Model pada Gambar 3 bertumpu pada Gapoktan/petani penangkar yang akan memperbanyak benih pokok menjadi benih sebar, lembaga keuangan mikro yang akan membantu pendanaan, atau koperasi yang akan menyediakan pupuk serta pembasmi hama dan penyakit. Kualitas benih yang dihasilkan dapat dipercaya mutunya karena benih yang dihasilkan disertifikasi oleh BPSB. Benih yang dihasilkan akan digunakan secara luas oleh Gapoktan dan petani atau diperdagangkan dalam kabupaten atau provinsi. Bila benih langsung digunakan, tidak ada masalah dengan viabilitas dan vigor benih. Permasalahan akan muncul bila benih akan diperdagangkan yang membutuhkan periode penyimpanan, dan jarang sekali para pedagang benih dilengkapi dengan fasilitas penyimpanan yang moderen.

Lalu lintas benih dengan sistem Jabalsim Terkendali dari dan ke Kabupaten Tanjung Jabung Timur melibatkan instansi pemerintah (BPTP), Kabupaten Muaro Jambi (BBI Sebapo), Kabupaten Bungo (BBI Margoyoso) dan Kabupaten Tebo (Kelompok Tani Penangkar di Desa Teluk Rendah). Lalu lintas benih tersebut disajikan pada Gambar 4.

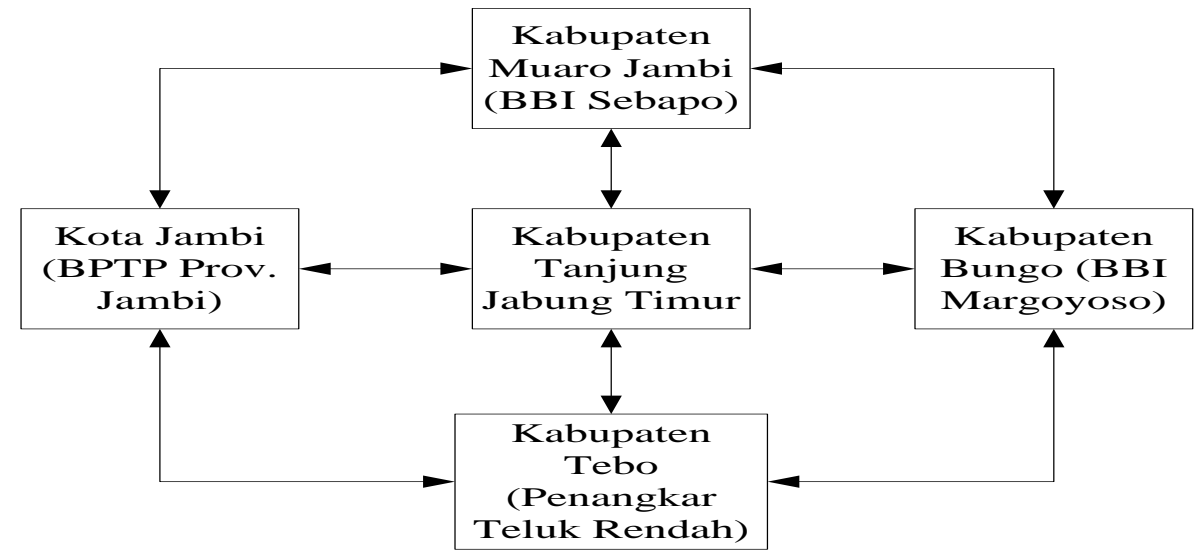

Gambar 4. Lalu lintas benih dengan sistem Jabalsim Terkendali dari dan ke Kabupaten Tanjung Jabung Timur

Lalu lintas benih dengan sistem Jabalsim Terkendali yang dikendalikan oleh instansi pemerintah atau kelompok tani yang bekerjasama dengan instansi pemerintah seperti Gambar 4 mengindikasikan pemerintah berperan penting dalam mengendalikan 
Jurnal Media Pertanian Vol. 2 No. 2 Tahun 2017 Hal. 73 - 84

Media Komunikasi Hasil Penelitian dan Review Literatur Bidang Ilmu Agronomi ISSN print $2503-1279$

ISSN online $2581-1606$

sistem Jabalsim. Hal seperti ini sangat wajar karena pemerintah akan menjaga wibawanya dengan penyediaan benih yang bermutu. Bagaimana kalau distribusi sistem Jabalsim yang terjadi Kabupaten Tanjung Jabung Timur didorong agar menjadi distribusi sistem Jabalsim Terkendali? Model yang diusulkan seperti pada Gambar 5 ini.

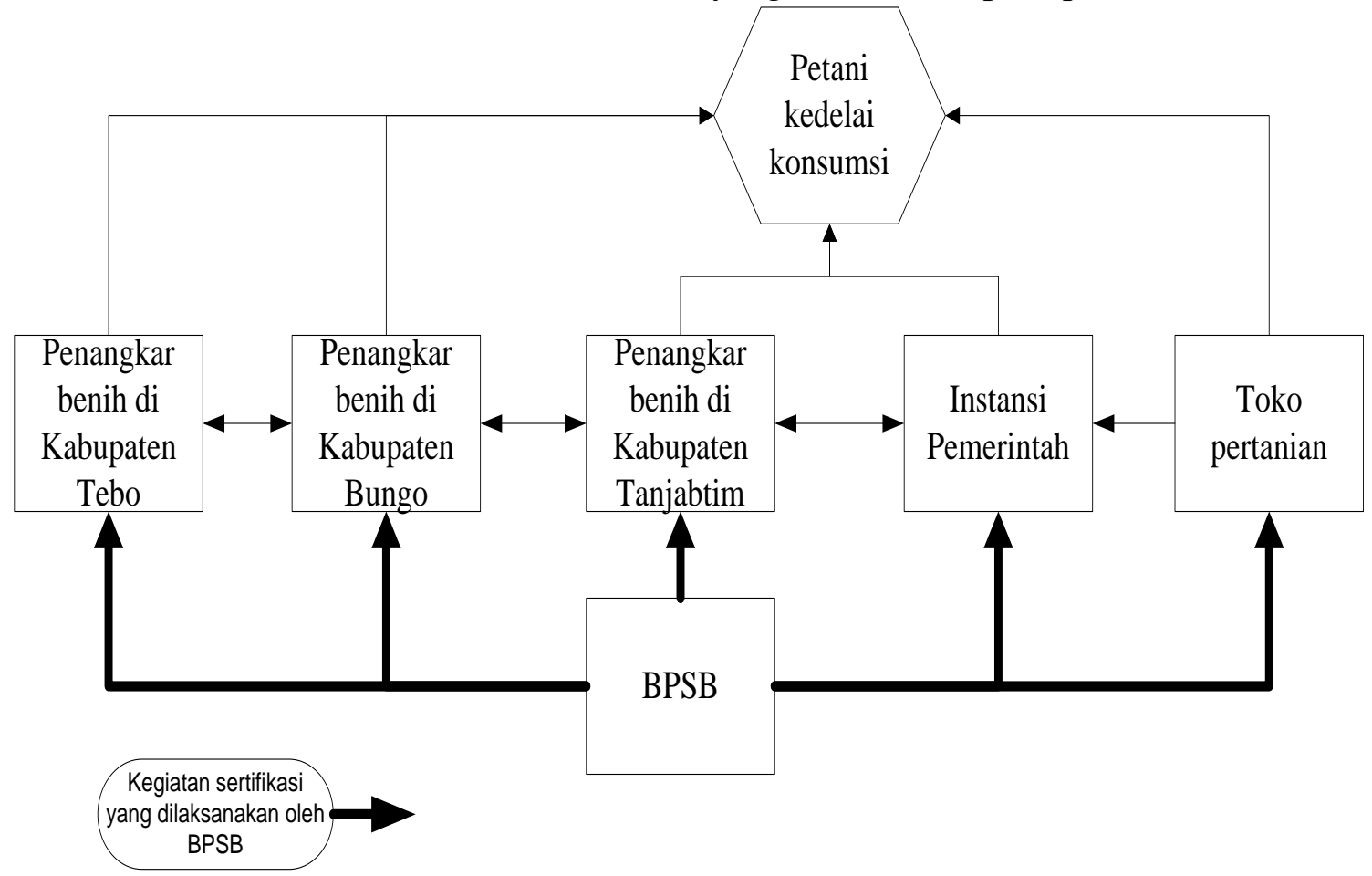

Gambar 5. Model migrasi dari Jabalsim ke Jabalsim Terkendali

Upaya migrasi dari sistem Jabalsim ke Jabalsim Terkendali harus melibatkan instansi pemerintah yang berwenang menerbitkan sertifikasi benih, dalam hal ini adalah BPSB Provinsi Jambi. Lembaga pemerintah ini akan menjalankan perannya kepada semua usaha yang akan menghasilkan benih. Keterlibatan BPSB tersebut dimulai dari pemeriksaan lapangan, pemeriksaan tanaman, pasca panen, pengambilan sampel benih sampai penerbitan sertifikasi. Model distribusi benih kedelai bermutu dalam sistem Jabalsim Terkendali disajikan pada Gambar 6.

Gambar 6 menginformasikan bahwa saat pertanaman April Juli, para penangkar umumnya mendapatkan benih dari instansi pemerintah. Pada pertanaman Juli-Oktober, para penangkar menggunakan benih produksi sendiri dengan label Marah Jambu. Produksi benih pada bulan Juli-Oktober di jual ke luar Kabupaten Tanjung Jabung Timur, karena pada umumnya kegiatan pertanaman terhenti karena banjir yang diakibatkan curah hujan yang tinggi. Pertanaman pada musim hujan hanya dilakukan pada daerah yang relatif tinggi. Kalau hal ini dilakukan maka benih yang dihasilkan akan digunakan sendiri di Tanjung Jabung Timur. Proses yang telah disebutkan ini merupakan gambaran Jabalsim yang pada akhirnya akan disempurnakan menjadi Jabalsim Terkendali. 
Jurnal Media Pertanian Vol. 2 No. 2 Tahun 2017 Hal. 73 - 84

Media Komunikasi Hasil Penelitian dan Review Literatur Bidang Ilmu Agronomi ISSN print $2503-1279$

ISSN online $2581-1606$

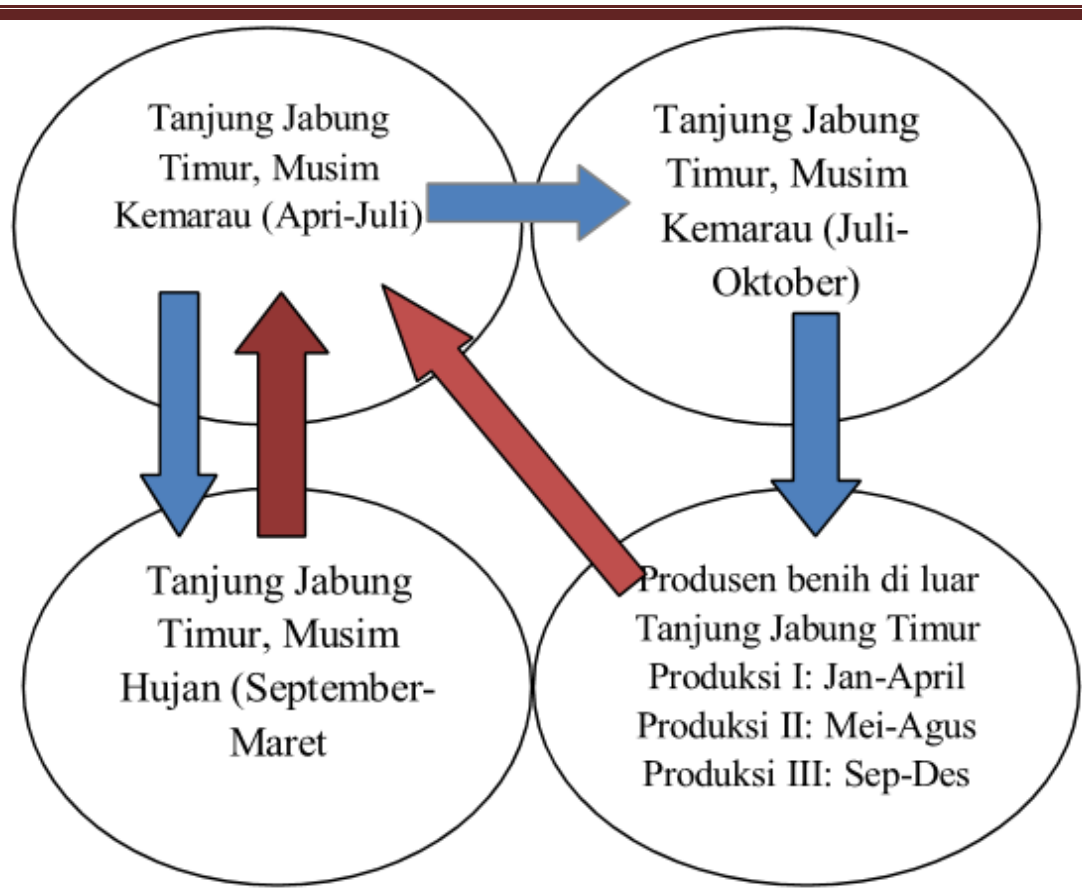

Gambar 6. Distribusi benih kedelai bermutu dalam sistem Jabalsim Terkendali

Pemantapan Jabalsim Terkendali akan meningkatkan keterlaksanaan prinsip penyediaan benih bermutu dengan prinsip 6 (enam) tepat. Peran penyuluh pertanian dalam meningkatkan pengetahuan petani juga sangat penting. Secara alami petani menggunakan benih hasil panen sendiri seperti yang dilakukan oleh tetua mereka. Pengubahan pola ini membutuhkan penyuluh pertanian yang secara intensif memberikan pengetahuan tentang kelemahan-kelamahan penggunaan benih produksi sendiri dan menganjurkan penggunaan benih bermutu.

Beberapa kebijakan yang dapat dilaksanakan pemerintah untuk meningkatkan penggunaan benih bermutu yang akan meningkatkan keberlanjutan Jabalsim Terkendali:

1. Pemerintah sebagai regulator perbenihan memiliki peran sangat penting untuk mengarahkan kebijakan perbenihan agar benar-benar menyentuh persoalan yang berdampak langsung pada pembangunan pertanian.

2. Meningkatkan peran dan fungsi Litbang Pertanian dalam menghasilkan benih penjenis (breeder seed), Dirjen Tanaman Pangan dalam menyediakan benih dasar (fondation seed) dan benih pokok (stock seed) dan Dinas Pertanian Provinsi dalam menyediakan benih sebar (extension seed)

3. Kalangan BUMN industri benih diminta untuk mamaksimalkan tugas dan fungsi pelayanan publik, khususnya dalam penyediaan benih unggul berkualitas.

4. Meningkatkan kualitas penerapan sistem enam tepat dalam upaya peningkatan penggunaan benih bermutu

5. Merevitalisasi BPP, Penyuluh Pertanian, dan Penyuluh Pertanian Spesialis untuk mensosialisasikan dan menjelaskan kepada petani untuk meningkatkan penggunaan benih bermutu

6. Mempertahankan fasilitas subsidi benih sampai ada penelitian yang pasti tentang kemandirian petani dalam menggunakan benih bermutu 
Jurnal Media Pertanian Vol. 2 No. 2 Tahun 2017 Hal. 73 - 84

Media Komunikasi Hasil Penelitian dan Review Literatur Bidang Ilmu Agronomi

\section{KESIMPULAN}

Distribusi benih kedelai di Kabupaten Tanjung Jabung Timur berjalan dengan sistem Jabalsim dan Jabalsim Terkendali. Sistem Jabalsim terjadi antara para petani penangkar dan Toko Pertanian, sedangkan Jabalsim Terkendali terjadi karena campur tangan pemerintah melalui Dinas Pertanian, BBI Sebapo dan BPTP Jambi.

Berdasarkan analisis SWOT terdapat masing-masing tiga kekuatan, kelemahan, peluang dan ancaman, Kekuatan yaitu: Kampanye yang masif dari PPL tentang pentingnya penggunaan benih bermutu, Benih bermutu terbukti memberikan hasil benih yang tinggi dan Benih bermutu berpeluang untuk mendapat sertifikat dari BPSB. Kelemahan yaitu: Prinsip enam tepat belum berjalan dengan baik, Harga benih masih dianggap tinggi oleh petani kedelai konsumsi dan Penanganan pasca panen dengan peralatan yang sederhana. Peluang: Areal pertanaman yang luas membutuhkan benih bermutu yang banyak, Bantuan benih pokok dari pemerintah untuk produksi benih sebar dan Benih bersertifikat dapat dijual lintas daerah. Ancaman yaitu : Benih kedelai dengan sertifikat palsu beredar di pasaran, Gagal sertifikasi karena proses budidaya dan pasca panen yang tidak tepat dan Benih tanpa sertifikat berharga rendah.

Strategi yang digunakan agar terjadi migrasi dari sistem Jabalsim ke Jabalsim Terkendali adalah dengan melibatkan BPSB Provinsi Jambi mulai dari proses pengajuan izin pertanaman sampai pengeluaran sertifikat sertifikasi.

\section{DAFTAR PUSTAKA}

Adie, M.M., N. Nugrahaeni, T. Sundari, Marwoto, I.K. Kariyasa, I.N. Widiarta dan D. Harnowo. 2013. Pedoman Umum Produksi dan Distribusi Benih Kedelai. Kementerian Pertanian. Jakarta

Badan Pusat Statistik. 2016. Tanjung Jabung Timur dalam Angka. Badan Pusat Statistik Tanjung Jabung Timur, Muara Sabak

Badan Standardisasi Nasional. 2003. SNI 01-6234.4-2003. Produksi Benih Kedelai Label Biru.Badan Standardisasi Nasional. Jakarta

Nengsih, Y dan R. Hartawan. 2016. Meningkatkan Ketersediaan Benih Kedelai Label Biru Dengan Pemberdayaan Kelompok Tani Penangkar. Prosiding Seminar Nasional Lahan Sub Optimal. Fakultas Pertanian Universitas Sriwijaya, Palembang 20-21 Oktober 2016.

Heriyanto. 2012. Upaya percepatan penyebaran varietas unggul Kedelai di Pulau Jawa. Balai Penelitian Kacang-kacangan dan Umbi-umbian. Malang

Nugroho, U. S. dan Subandi. 2002. Perkembangan teknologi Budidaya dan Industri benih. Diskusi Nasional Agribisnis Jagung. Badan Penelitian dan Pengembangan Pertanian. Departemen Pertanian. Bogor 24 Juni 2002.

Nurasa, T. 2007. Revitalisasi benih dalam meningkatkan pendapatan petani kedelai di Jawa Timur. Jurnal Akta Agrosia. Edisi Khusus. 2: 164-171

Rozi, F. 2008. Membangun sistem perbenihan Kedelai dengan pendekatan supply chain managemen. Dalam Basuki et al. Peran Perbenhan dan Kelembagaan dalam Memperkokoh Ketahanan Pangan. Prosiding Seminar Nasional dan Workshop Perbenihan dan Kelembagaan. Fakultas Pertanian UPN Yokyakarta-Forum Perbenihan Komda DIY. Yokyakarta

Singarimbun, M dan S. Effendi. 2008. Metode Penelitian Survei, LP3ES. Jakarta

Sugiyono. 2009. Metode Penelitian Kuantitatif Kualitatif dan R\&D. Alfabeta. Bandung. 
Jurnal Media Pertanian Vol. 2 No. 2 Tahun 2017 Hal. 73 - 84

Media Komunikasi Hasil Penelitian dan Review Literatur Bidang Ilmu Agronomi ISSN print $2503-1279$

ISSN online $2581-1606$

Supadi. 2008. Menggalang partisipasi petani untuk meningkatkan produksi kedelai menuju swasembada. Jurnal Litbang Pertanian. 27: 106-111

Suryana, A. 2009. Kebijakan dan program penelitian mendukung tercapainya swasembada kedelai dan ubi kayu. Prosiding Seminar Nasional Inovasi Teknologi Kacang-kacangan dan Umbi-umbian mendukung Kemandirian Pangan dan Kecukupan Energi. Ballitan Malang. 